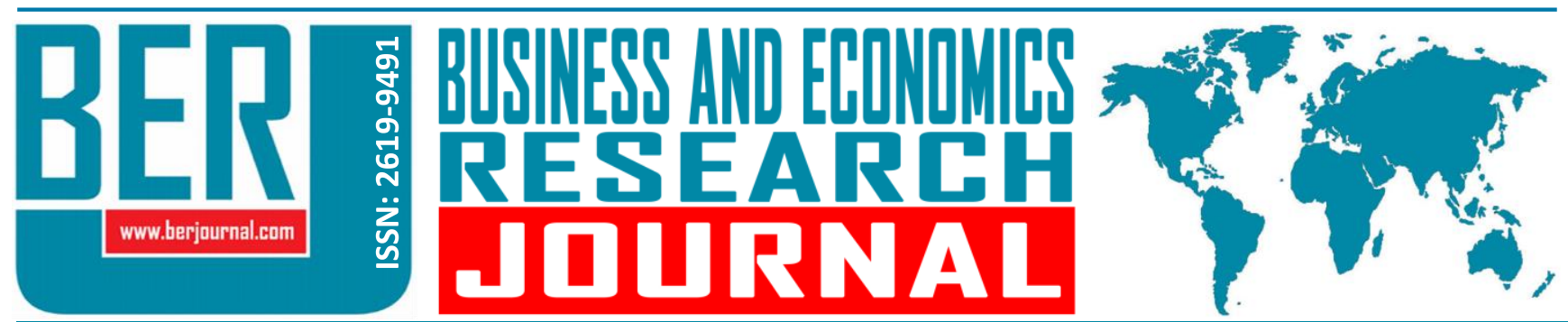

Business and Economics Research Journal Vol. 11, No. 1, 2020, pp. 107-118 doi: 10.20409/berj.2020.238

\title{
On the Relationship between Operational Risk and Tunisian Banks Performance: Does the Interaction between the Other Risks Matter?
}

\begin{abstract}
Abdelaziz Hakimia , Sid'Ahmed Boukaira ${ }^{\text {b }}$
Abstract: The main purpose of this paper is to investigate the interactional relationship between operational risk, credit risk, liquidity risks and the Tunisian bank performance. We used a sample of Tunisian banks over the period 1990-2017. Results of the panel data analysis show that an increase in required capital charge to hedge operational risk significantly increases the level of bank performance. Findings also indicate that the interaction between operational risk and loan activities exerts a positive and significant effect on the level of bank performance. However, no significant effect of the interaction between operational and liquidity risk was found. These results could bring some important policy recommendations to policymakers toward the reinforcement of the capital charge and for improving the analysis and the management process of bank risks.
\end{abstract}

Keywords: Operational Risk, Loans Activity, Liquidity Risk Tunisian Banks, Panel Data Analysis

JEL: F30, G21, O16, L25

Received : 16 September 2019

Revised : 19 November 2019

Accepted : 03 December 2019

Type : Research

\section{Introduction}

It is obvious that banks play a crucial role in the economy financing. This role becomes more announced in emerging economy when financial markets are less developed and less dynamic. For these economies, the most important role of finance is devoted to the banking sector. From the one hand, banks operate and search to be more efficient since it is even the raison d'être of this activity. From the other hand, banks are faced to multiple and complex risks that threaten their stability and their survival.

Literature on the effect of credit and liquidity risks on bank performance is strongly documented (Kithinji, 2010; Kargi, 2011; Arif \& Nauman, 2012; Hakimi \& Zaghdoudi, 2017; Hamdi \& Hakimi, 2019). However, less abundant studies those are focused on the operational dimension, its determinants and its effect on the bank performance. Furthermore, the few empirical studies that are focused on the relationship between operational risk and bank performance provide mixed and inconclusive results. Some authors have found that operational risk does not have any significant effect on the level of bank performance (Micco et al., 2007; Athanasoglou et al., 2008; Muriithi \& Waweru, 2017). In contrary, others studies have concluded that operational risk increases the level of bank performance (Bikker et al., 2002; Pasiouras \& Kosmidou, 2007; Al-Tamimi et al., 2015).

a V.P.N.C Lab, University of Jendouba, Faculty of Law, Economics and Management of Jendouba, Tunisia, abdelazizhakimi@yahoo.fr (ORCID ID: 0000-0003-2715-0239)

b V.P.N.C Lab, University of Jendouba, Faculty of Law, Economics and Management of Jendouba, Tunisia, boukaira@yahoo.fr (ORCID ID: 0000-0002-6816-6088) 
The controversy around the effect of operational risk on bank performance motivates us to study this relationship for the Tunisian context. Basically, the purpose of this paper is to study the dynamic relationship between operational risk and bank performance. Moreover, we investigate the interaction effect of operational risk, credit and liquidity risk on the Tunisian bank performance.

To achieve these goals, we used bank-level data relating to the ten (10) largest Tunisian banks over the period 2000-2017. We choose these banks since they are the most involved in the financing of the Tunisian national economy. Also, they are the most ranked in terms of the volume of their total assets and total deposits. To control the macroeconomic environment in which operate Tunisian banks, we include two macroeconomic variables: the growth rate of GDP and the inflation rate. The main sources of data are the annual reports of banks, and the World Bank databases.

Taking into the individual and the temporal dimensions and since the number of years $(N=18)$ is greater than the number of banks $(\mathrm{i}=10)$, we performed the static panel data analysis instead of the dynamic panel data. The empirical strategy of this paper is based on three steps. In the first step, we separately test the impact of the operational risk proxied by the capital requirements in the basic indicators approach on the level of bank performance. The second step is therefore to test the impact of the interaction effect of operational risk-loans activities on the level of bank performance. While in the third step, we examine the interaction effect between operational risk and liquidity risk.

Theoretically, this study contributes to the existing literature in two ways. First, most of studies on bank risks are focused either on credit or liquidity risks as the two serious risks. However, less abundant studies that are carry out on operational risk. To the best of our knowledge, there are no studies that are focused on the effect of operational risk on the Tunisian bank performance. Second, the choice of the Tunisian context is justified by the crucial role of banking sector in the financing of the Tunisian economy. Banks are considered as the most involved financial institutions which provide necessaries funds for investment. In some indebted countries, the stability of the entire economy depends on the banking system stability. Hence, it is very useful to study the interactional effect of bank risks on the bank performance.

Empirically, contrary to previous studies that carry out either on the credit or liquidity risks, this current focuses on one of the most complex risk. We assess the effect of bank risks on bank performance following three steps. First, we test the effect of operational risk on bank performance. Second, we explore the interactional effect between operational risk and credit risk. Third, we investigate the effect of operational risk and liquidity risk.

The rest of this paper is articulated as follow. Section 2 presents a brief literature review. An overview of the Tunisian banking sector is given in section 3. The methodology adopted for this paper is introduced in section 4 . We present and we discuss descriptive and empirical results in the section 5 . Section 6 concludes and addresses some policy implications.

\section{Literature Review}

The relationship between operational risk and bank performance is one of the least discussed topics in banking literature. Results around this topic are inconclusive and clearly perceptible. As for example, Muriithi and Waweru (2017) used a qualitative approach to identify the causes of bank losses that affect the shareholder returns of commercial banks in the Kenyan context. They measure financial performance through return on equity. Operational risk was proxied through the following dimensions: internal and external fraud (IEF), customers, products and business practices (CPBP), business interruption and system failure (BDSF) and execution, delivery and process management (EDPM). Empirical findings indicate that operational risk negatively affects the financial performance. They also showed that the negative effect of the four dimensions of operational risk is relatively important for bank profitability.

More recently, Olalere et al. (2018) studied the impact of operational risks on the bank performance. They used a sample of (16) commercial banks in Nigeria selected for the period from 2009 to 2015 and they performed the panel data analysis as econometric approach. The bank performance is measured by the net 
interest margin, while the operational risk is represented by the cost/income ratio, and total operating expenses/total assets. Results show that the bank efficiency ratio has a significant and negative effect on the business performance. While the ratio of operating expenses has a significant and positive effect on the level of performance. Findings also indicate that the bank size do not exert any significant effect. While GDP plays an important role in the performance of commercial banks during the study period.

Al-Tamimi et al. (2015) examined the relationship between banking risks and the performance of Islamic banks in the Gulf countries. The sample covers 47 banks over the period 2000-2012. Their results support a negative and significant relationship between the performance of Islamic banks and operational risk.

In a recent study, Gadzo et al. (2019) explored the effect of operational risk on the financial performance of universal banks in Ghana, using the structural equation model (SEM). The data collected are related to 24 universal banks. They found that the operational risk has a negative impact on the bank financial performance. In addition, results show that certain bank-specific variables measured by asset quality, bank indebtedness, cost/income have a significant and positive influence on both operational risk and financial performance of universal banks.

However, banking literature states that operational risk could affect bank performance across several variables such as the size of banks. For example, Bikker et al. (2002) and Pasiouras et al. (2007) found a positive relationship between the bank size of the level of performance. This result could be explained by the fact that large size reduces costs through the economies of scale. This result is sharply contradicted by Kasman (2010). The author used a sample of 431 banks spread over 39 countries and found a negative impact of the bank size on the level of performance.

Other researches, such as that of Micco et al. (2007) and Athanasoglou et al. (2008) found no relationship between the bank size and the level of performance. However Stiroh and Rumble (2006) reported that an increase in bank size causes more difficulties in the level and the quality of management, and more particularly at the level of the coordination function.

Besides bank specifics, there are other external factors also called industry specifics and macroeconomic factors that can be considered as determinants in the operational risk- performance relationship. As for example, we quote the level of competition-concentration, the mergers and acquisition operations, the growth of the GDP, and the inflation.

Literature relating on the effect of market concentration on bank performance has distinguished two radically opposed theories. The first one is the Structure-Conduct-Performance Theory (SCP) and the second one is the Efficient -Structure Theory (ES). According to the SCP theory articulated around the work of Molyneux and Thornton (1992), there is a positive association between market concentration and bank performance. In concentrated market it results a quasi-monopoly position and subsequently, the possibility of imposing high prices for their products and to pay low costs on the used resources. In this case, the interest margin increases that leads also to an increase in the level of bank performance. While the ES theory, whose main followers are Staikouras and Wood (2004), it adopts a position radically opposed to the first one.

For the effect of macro-economic environment, Bikker and $\mathrm{Hu}$ (2002) and Schwaiger and Liebig (2008) have found a positive relationship between GDP growth and banking performance. This could be justified by the fact that in the periods of economic growth it results a high demand for loans of, which in turn will lead to an increase in the interest revenues that increase bank performance. With regard to the effect of the inflation rate, Revel (1979) tested the linkage between inflation and bank performance. He found that when the growth rate of inflation is lower than the expenditure, the impact of inflation is positive and vice versa. Following Revel (1979), Perry (1992) has introduced the concept of anticipation. According to this author, when inflation is not anticipated, costs will increase in a faster rhythm than the prices of products, which will have a negative impact on the banks' performance. Furthermore, in their study, Ben Naceur and Kandil (2009) conclude that inflation has a negative impact on banks' performance, due to the decrease in credit demand that consequently decrease the bank interest margin. 


\section{An Overview of the Tunisian Banking System}

Banks play a crucial role in the economy financing. For some indebted economies, their stability is closely linked to the stability of banking system. Like several emerging market, Tunisian banking system is considered as the important source of financing especially for private sector and small medium size enterprises (SME). According to the statistics of the World Development Indicators (WDI), domestic credit provided by banking sector (\% of GDP) in Tunisia reached very attractive levels. As for example, this level was reported at $79.33 \%$ in $2015,81.15 \%$ in 2016 and $85.58 \%$ in 2017.

Actually, the Tunisian banking sector is composed of 29 institutions, including 11 listed banks, with a market capitalization of 8 billion dinars in 2015. The banking sector is the primary market force, accounting for $41 \%$ of total capitalization. There are three public banks with $38 \%$ of the total assets. These three banks are considered as the most involved in the financing of the economy.

Since 1987, the Tunisian banking sector has undergone significant structural reforms over the past three decades. Those reforms are carried out in order to have a more dynamic and modern banking system. It should be noted, that the reforms of the Tunisian banking system are induced by the adoption of the structural adjustment program (SAP) suggested by the International Monetary Fund.

In relation with the issue of this paper, it has been more emphasis in analyzing the evolution of the capital charges required to hedge operational risk and the evolution of the net interest margin. This evolution will be studied annually and across banks ${ }^{1}$. Figures below give some trends on these evolutions. It is worth recalling that we have limited our study to 10 banks since there are the most dynamic and they monopolize the most important share of total assets, total credits and total deposits. Values related to capital charge are in millions of dinars (MD), however values of net interest margin (NIM) are in \%.

Figure 1. Average Annual Evolution of NIM

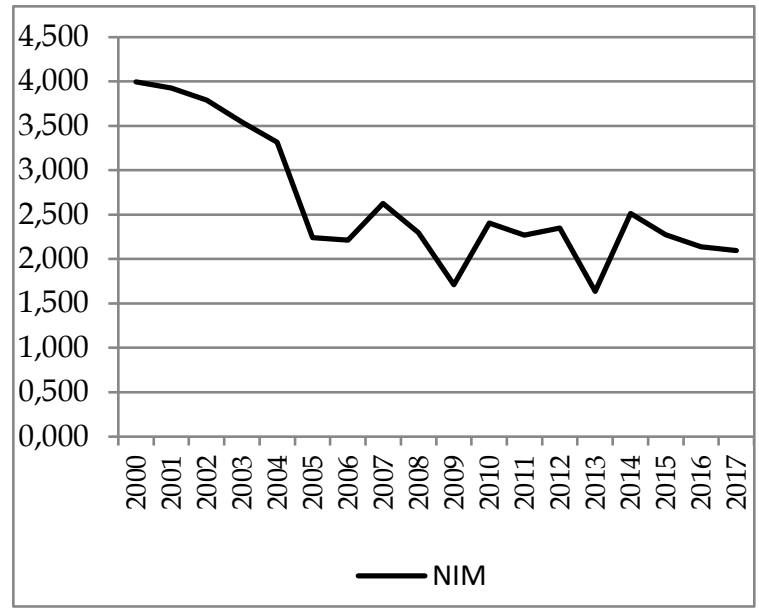

Figure 2. Average Annual Evolution of Capital Charges

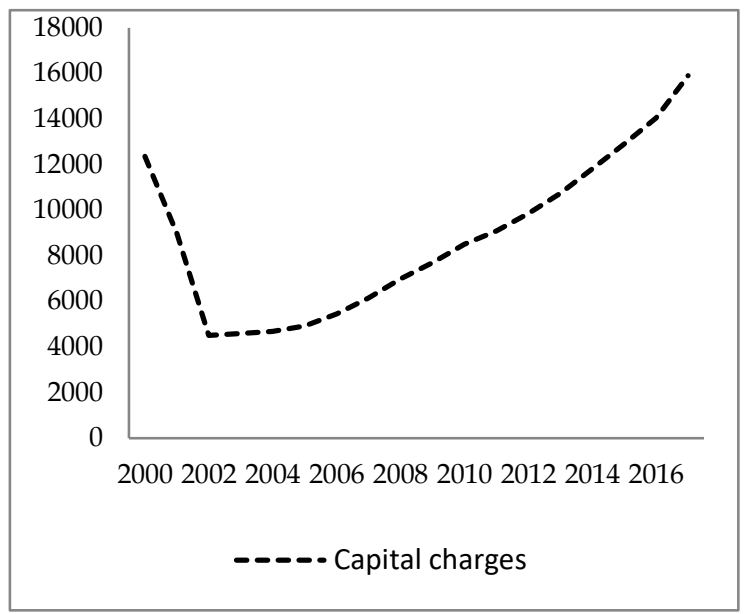

Figures 1 and 2 above present the annual evolution of net interest margin (NIM) and capital charges required to hedge operational risk for Tunisian banks during the period 2000-2017. From Figure 1, we notice that net interest margin have registered fluctuated trends. We can analyze the evolution of the net interest margin according two phases. The first one covers the period 2000-2006 when the NIM registered a downward trend. Net interest margin crossed from $4 \%$ in 2000 to become $2.22 \%$ in 2006. The second one spreads over the time span 2007-2017 when NIM records several fluctuations. During the period of study, net interest margin registered an average level greater than 2\% except for two years 2009 and 2013. For these two years, Tunisian banks recorded on average a level of $1.71 \%$ and $1.64 \%$ respectively.

Figure 2 indicates on the average annual evolution of capital charges necessary to hedge operational risk during the period 2000-2017. For this indicator, we can also interpret its evolution according two phases. 
The first phase is relative to the period 2000-2005, which is qualified as a period with downward trend. The required capital charges necessary to hedge risk operational is still decreasing. It was $12364.78 \mathrm{MD}$ in 2000 and records a level of $4924.72 \mathrm{MD}$ in 2005. However, from 2006 to 2017, the required capital records a bullish trend. The level of capital charges was 5455.11 MD in 2006 and becomes 15903.27 in 2017. This increase can be explained as follow. Since a capital charge is calculated as $15 \%$ of net banking income (NBI), this means that Tunisian banks have recorded high level of NBI. We can conclude also that Tunisian banks assign a great importance to hedge the operational risk which leads for keeping an important level of capital which able to provide cover for operational risk.

After analyzing the annual evolution of the NIM and the capital charge, we aim in the following development to examine the evolution of these tow indicators across banks. Figures 3 and 4 below indicate these bank evolutions ${ }^{2}$.

Figure 3. Evolution of NIM per Banks

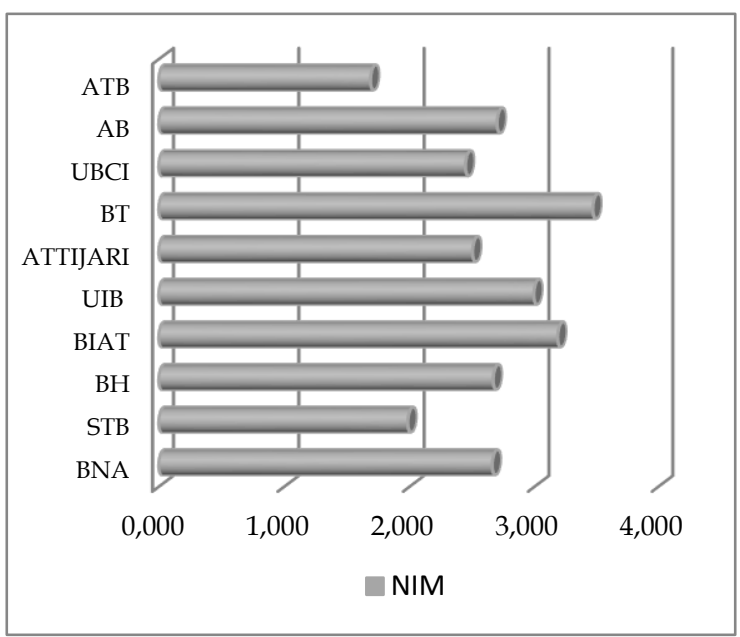

Figure 4. Average Evolution of Capital Charges per Banks

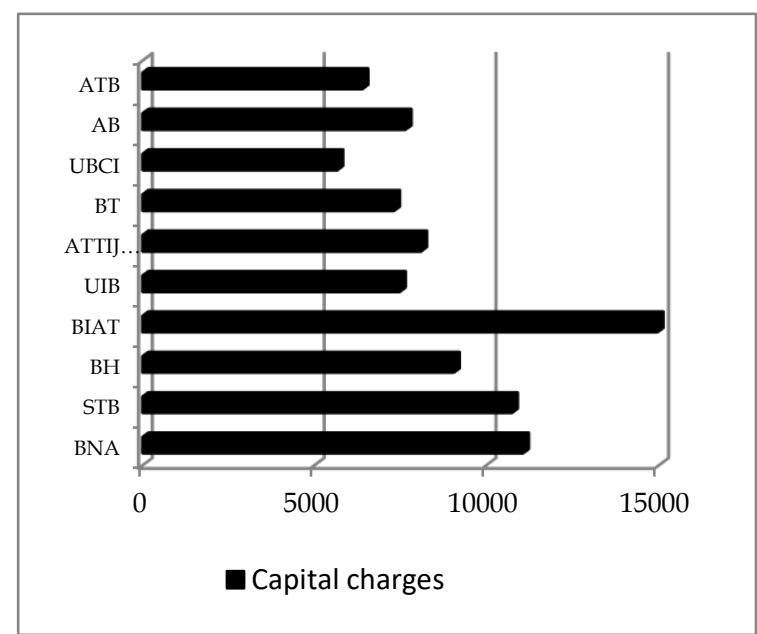

From Figure 3, we acknowledge that private banks are the most efficient with regard to the NIM. Firstly, we found that the Tunisian bank (BT) with an average NIM of 3.74\%. Secondly, the International Arab Tunisian Bank (BIAT) which registered a level of 3.18\%. The international Union of Banks (UIB) comes at the third place with a level of performance of $2.99 \%$. The weakest level of performance is recorded by Arab Tunisian Bank (ATB) bank with a level of $1.68 \%$ and by the state-owned banks. The STB bank was considered as the least efficient bank with a level of NIM only of $1.98 \%$. This bank is followed by the National Agricultural Bank (BNA) bank with a level of $2.66 \%$.

From these descriptive statistics related to bank performance, we found that state-owned banks are the less efficient. However, private banks are recognized as the most efficient.

Figure 4 presents the level of capital charges required to hedge operational risk. We notice the BIAT requires more capital with an amount of $14962 \mathrm{MD}$. This bank is followed by the BNA with a level of capital charges of 11065 MD. However, the Union Banks of Trade and Industry (UBCI) and the ATB required less capital charges with respectively $5665 \mathrm{MD}$ and $6394 \mathrm{MD}$.

\section{Methodology}

In this section, we present the methodology adopted for this study. In other words, we introduce our data, their sources and the empirical approach. Second, we specify the empirical models and we define precisely all variables and their measurements. 


\subsection{Data}

To investigate the effect of operational risk and its interaction with credit and liquidity risks on the level of performance, we use bank-level data related to ten (10) banks ${ }^{3}$ over the period 2000-2017. We have selected only 10 banks since they are considered as the most dynamic and the most involved in the Tunisian economy financing. Also, these banks monopolize the most important share in term of total assets, total credit and total deposit ${ }^{4}$.

Variables relative to bank specifics are collected from the annual report of each bank during the period 2000-2017. However, variables that represent macroeconomic conditions are collected the World Bank Indicators (WDI) databases during the same period.

The presence of the two dimensions; individual (10 banks) and temporal (18 years), in our sample motivates us to perform the panel data analysis. We apply for the static panel data instead of dynamic panel data since the number of years $(\mathrm{N})$ is greater than the number of banks (i).

\subsection{Empirical Approach, Model Specification and Variables Definition}

To investigate the impact of the interaction between operational risk and other banks risks for the Tunisian context, we follow an empirical approach based on three steps.

In the first step, we test separately the impact of operational risk proxied by the capital charges within the Basic Indicator Approach (KBIA), loans activity (credit risk) and liquidity risk on bank performance. We aim at this step to examine the individual effect of each bank risk. The econometric model relative to the first step can be written as follow:

$$
\begin{aligned}
& N_{M} M_{i, t}=B_{0}+B_{1} K B I A_{i, t}+B_{2} L O A C T_{i, t}+B_{3} L I Q R_{i, t}+B_{4} S I Z E_{i, t}+B_{5} C A P_{i, t}+B_{6} H H I_{i, t}+B_{7} G D P G_{t}+B_{8} \\
& I N F_{t}+\varepsilon_{i, t}
\end{aligned}
$$

Besides the individual impact of bank risks, we think that the interaction between operational risk and loans activity (credit risk) may affect the level of bank performance. Hence, the second step consists to test the impact of this interaction on bank performance for the Tunisian banks. The second model can be expressed as follow:

$$
\begin{aligned}
& \operatorname{NIM}_{i, t}=B_{0}+B_{1} \text { KBIA }^{*} \text { LACT }_{i, t}+B_{2} \text { LIQR }_{i, t}+B_{3} \text { SIZE }_{i, t}+B_{4} \text { CAP }_{i, t}+B_{5} H H I_{i, t}+b_{6} \text { GDPG }_{t}+b_{7} \text { INF }_{t} \\
& +\varepsilon_{i, t}
\end{aligned}
$$

In the third step, we examine the impact of the interaction between operational risk and liquidity risk. The model 3 is presented as follow:

$$
\begin{aligned}
& N_{i, M_{i, t}}=B_{0}+B_{1} \text { KBIA }^{*} \text { LIQR }_{i, t}+B_{2} \text { LOACT }_{i, t}+B_{3} \text { SIZE }_{i, t}+B_{4} \text { CAP }_{i, t}+B_{5} H H I_{i, t}+B_{6} \text { GDPG }_{t}+b_{7} \text { INF }_{t} \\
& +\varepsilon_{i, t}
\end{aligned}
$$

In this study, we use variables relative to bank specifics and others relative to macroeconomic conditions. All definitions and measurements of these variables are given in Table 1. 
Table 1. Definition and Measurement of Variables

\begin{tabular}{|c|c|c|}
\hline Variables & Definition & Measurement \\
\hline NIM & Net Interest margin & Ratio of interest margin to total Assets \\
\hline KBIA & $\begin{array}{l}\text { Capital charges to hedge } \\
\text { operational risk }\end{array}$ & $\begin{array}{l}\text { Basic Indicator Approach }{ }^{5} \text { the average over the previous } \\
\text { three years of a fixed percentage (denoted } \alpha \text { ) of positive } \\
\text { annual gross income. }\end{array}$ \\
\hline LOACT & Loans activity & Total loans to total assets. \\
\hline KBIA*LOACT & Interaction variable & $\begin{array}{l}\text { The interaction between operational risk and loan } \\
\text { activities. }\end{array}$ \\
\hline KBIA*LIQR & Interaction variable & The interaction between operational risk and liquidity risk. \\
\hline CAP & Capital adequacy ratio & Ratio of total equity to total assets \\
\hline SIZE & Bank size & Napierian logarithm of total assets \\
\hline LIQR & Liquidity risk & Loans to deposit ratio. \\
\hline HHI & Hirshmen Herfindahl index & The squared sum of market share of total assets. \\
\hline GDP & Gross domestic product & Growth rate of Gross domestic product \\
\hline INF & Inflation rate & Customer index price \\
\hline
\end{tabular}

\section{Discussion of Results}

In this sub-section, we firstly analyze our data. Some descriptive statistics are given to have more information about the sample used in this study. For each variable, we interpret the average value, the minimum and the maximum value. Second, we examine the correlation between dependent variables to check for the multicollinearity problem. Third, we discuss empirical findings. Table 2 informs about descriptive statistics.

Table 2. Descriptive Statistics

\begin{tabular}{lccccc}
\hline Variable & Obs & Mean & Std. Dev. & Min & Max \\
\hline Nim & 180 & 0.026 & 0.010 & 0.004 & 0.059 \\
Kbia & 180 & 8844.129 & 4772.449 & 2203.483 & 30458.170 \\
Loact & 180 & 0.771 & 0.095 & 0.513 & 0.965 \\
Liqr & 180 & 1.174 & 0.360 & 0.636 & 2.597 \\
Kbiaxloact & 180 & 6944.299 & 4007.285 & 1561.303 & 24584.670 \\
Kbiaxliqr & 180 & 10197.73 & 5438.807 & 1935.136 & 28616.46 \\
Cap & 180 & 0.090 & 0.031 & 0.003 & 0.175 \\
Size & 180 & 14.934 & 1.007 & 7.609 & 16.421 \\
hhi & 160 & 0.107 & 0.009 & 0.088 & 0.116 \\
Gdpg & 180 & 0.033 & 0.020 & -0.019 & 0.067 \\
Inf & 180 & 0.039 & 0.011 & 0.020 & 0.058 \\
\hline
\end{tabular}

Table 2 indicates that the average level of bank performance (NIM) is $2.6 \%$. The maximum value for our sample during the period $2000-2017$ was $5.9 \%$. However, Tunisian banks record $0.4 \%$ as a minimum value of net interest margin. From this level, we conclude that Tunisian banks registered positive value of NIM during all the period of our study.

For the capital charge necessary to hedge operational risk, Tunisian banks maintain on average 8844.129 MD to hedge this risk. The maximum value is 30488.17 MD while the minimum value is about 2203.483MD. From these levels of capital charge, we conclude that Tunisian banks grant a great of importance for this risk. 
Loans are considered as one of the most important functions of banking activities. For this reason, we introduce a proxy of credit risk (loans activity). This variable records on average $77.1 \%$. This means that, on average loans represent more than $77 \%$ of total assets. The maximum value is $96.5 \%$, while the minimum value represents more than $51 \%$.

Conversely to loans activities, Tunisian banks are faced to the liquidity risk. Banks operate on the basis of liquidity which is considered as an important determinant of bank performance. Statistics in Table 2 indicate that the average level of liquidity risk is $117.4 \%$ with a maximum value of $259.7 \%$ and a minimum of $63.6 \%$

Besides liquidity, capital remains more important for banking activities and survives. A high level of capital indicates that banks are well capitalized and consequently more stable and more efficient. However, less level of capital indicates that banks are more vulnerable to chocks and crises. For our sample, the average value for the capital adequacy ratio is $9 \%$ with a minimum of $0.3 \%$ and a maximum of $17.5 \%$. From these values, we conclude that our sample contains well capitalized bank with a level of capital to total assets equal to $17.5 \%$. This level does not prevent the existence of banks that are less capitalized with a ratio only of $0.3 \%$.

Size is recognized in the banking literature as a key factor that determines bank performance. Its impact is still inconclusive since literature has been divided into positive and negative effects. The average size for the sample used in this study is 14.93 and its maximum is 16.421 .

With regard to the macroeconomic conditions, Table 2 indicates that the average of GDPG is $3.3 \%$. During the period 2002-2017, the highest level of growth was $6.7 \%$ while the weakest level was $-1.9 \%$. For the inflation rate, Tunisia records on average a level of 3.9\%. During the same period of study, the maximum level of inflation is $5.8 \%$ and the minimum level is $2 \%$.

To check for multicollinearity problem, Table 3 presents the level and the nature of correlation between variables used in this study.

Table 3. Correlation Matrix

\begin{tabular}{|c|c|c|c|c|c|c|c|c|c|c|c|c|}
\hline Variables & & (1) & (2) & (3) & (4) & (5) & (6) & (7) & (8) & (9) & (10) & (11) \\
\hline nim & (1) & 1.0000 & & & & & & & & & & \\
\hline Kbia & (2) & -0.0718 & 1.0000 & & & & & & & & & \\
\hline Loact & (3) & -0.0027 & 0.2755 & 1.0000 & & & & & & & & \\
\hline Liqr & (4) & -0.0945 & -0.1108 & 0.0725 & 1.0000 & & & & & & & \\
\hline Kbiaxloact & (5) & -0.0748 & 0.9799 & 0.4447 & -0.0939 & 1.0000 & & & & & & \\
\hline Kbiaxliqr & (6) & -0.0928 & 0.8568 & 0.3059 & 0.3772 & 0.8516 & 1.0000 & & & & & \\
\hline Cap & (7) & 0.1977 & -0.0517 & -0.0421 & 0.2554 & -0.0521 & 0.1174 & 1.0000 & & & & \\
\hline Size & (8) & -0.1592 & 0.1855 & 0.1118 & -0.1570 & 0.1979 & 0.0713 & 0.0107 & 1.0000 & & & \\
\hline hhi & (9) & 0.2475 & -0.2649 & -0.4629 & 0.3344 & -0.3562 & -0.0558 & 0.2054 & -0.4823 & 1.0000 & & \\
\hline Gdpg & (10) & 0.1946 & -0.3180 & -0.2942 & 0.2279 & -0.3522 & -0.1724 & 0.1233 & -0.2363 & 0.4120 & 1.0000 & \\
\hline $\operatorname{lnf}$ & (11) & -0.4471 & 0.3508 & 0.4143 & 0.0043 & 0.4127 & 0.3083 & -0.1626 & 0.2094 & -0.4755 & -0.1005 & 1.0000 \\
\hline
\end{tabular}

From Table 3, we notice that the level of correlation between variable is very low which confirm the absence of high correlation between independent variables. We registered high correlation between operational risk (KBIA) and its interaction between loan activities and liquidity risk. To solve this problem, we separately tested these variables in the three models.

It is worth recalling that we follow three steps to investigate the impact of operational risk on bank performance. The first one tests separately the impact of operational risk (KBIA), loans activity (credit risk) and liquidity risk on bank performance (model 1 ). The second one examines the impact of the interaction between operational risk and loans activity (model 2). The third one analyzes the interaction effect between operational risk (KBIA) and liquidity (model 3). Table 4 below gives empirical results of the three models. 
Table 4. Empirical Findings

\begin{tabular}{|c|c|c|c|c|c|c|}
\hline \multirow[b]{2}{*}{$\mathrm{Nim}$} & \multicolumn{2}{|c|}{ Model (1) } & \multirow{2}{*}{$\begin{array}{r}\text { Model (2) } \\
\text { Coef. }\end{array}$} & \multicolumn{3}{|c|}{ Model (3) } \\
\hline & Coef. & z-stat. & & z-stat & Coef. & z-stat. \\
\hline Kbia & 0.080 & $2.600 * * *$ & - & - & - & - \\
\hline Loact & 0.031 & $3.110 * * *$ & - & - & 0.022 & $2.060^{* *}$ \\
\hline Liqr & -0.008 & $-4.450 * * *$ & -0.007 & $-3.850 * * *$ & - & - \\
\hline Cap & -0.022 & -0.810 & -0.026 & -0.940 & -0.040 & -1.360 \\
\hline Size & -0.001 & -1.010 & -0.002 & -1.050 & 0.003 & 0.160 \\
\hline Hhi & 0.220 & $2.290 * *$ & 0.132 & 1.450 & 0.065 & 0.650 \\
\hline Gdpg & 0.104 & $2.301^{* *}$ & 0.089 & $2.460^{* *}$ & 0.090 & $2.310^{* *}$ \\
\hline $\operatorname{lnf}$ & -0.472 & $-6.670 * * *$ & -0.431 & $-6.120 * * *$ & -0.488 & $-6.370 * * *$ \\
\hline Kbia*loact & - & - & 0.037 & $3.083 * * *$ & - & - \\
\hline Kbia*liqr & - & - & - & - & -0.002 & -0.130 \\
\hline _cons & 0.023 & 0.860 & 0.055 & 2.140 & 0.019 & 0.640 \\
\hline Hausman test & 3.66 & & 2.320 & & 7.40 & \\
\hline Prob & 0.822 & & 0.888 & & 0.285 & \\
\hline Wald chi 2 & 106.95 & & 96.010 & & 65.87 & \\
\hline Prob $>$ chi 2 & 0.000 & & 0.000 & & 0.000 & \\
\hline R2 & 0.425 & & 0.403 & & 0.318 & \\
\hline OBS & 180 & & 180 & & 180 & \\
\hline
\end{tabular}

Results displayed in Table 4 indicate that the capital charges required to hedge operational risk is positively and significantly correlated with the net interest margin. An increase of $1 \%$ in capital charges increases bank performance by $8 \%$. Banks with sufficient level of capital are able to hedge and to well manage their risks. However, banks with less required capital charge recorded less profitability since they are more exposed to negative consequences of this risk and to more bank fragility.

With regard to the effect of the interaction between capital charges (operational risk) and loans activity (credit risk), findings indicate a positive and significant association with the net interest margin. This result can be explained as follow. Having sufficient capital charge and dynamic loans activity with sufficient required guarantees, banks can more profit from interest revenues that increase bank performance. However, no significant effect of the interaction between operational risk and liquidity risk.

Loans activity as proxy of credit risk exerts a positive and significant effect on the level of bank performance. The fundamental objective of each financial institution is realizing higher profit and minimizing risks. Tunisian banks are based on classic activities. Hence, more loans with sufficient guarantees generate more interest revenues that increase the net interest margin.

Contrary to the effect of loans activity, findings indicate that liquidity risk measured by the loans to deposit ratio decreases significantly the Tunisian bank performance. An increase of $1 \%$ in the liquidity risk decreases bank performance by $0.8 \%$ for model (1) and $0.7 \%$ for model (2). Banks operate on the basis of liquidity which is considered as the main important input. Hence, banks with insufficient level of liquidity are enabling to response partial or integral withdraw. Also, Banks with insufficient liquidity may undergo the decline in their interest income that decreases the level of bank performance. Moreover; less liquid banks are more prone to banking fragility and crises. These results are in line with Bourke (1989), Demirgüç-Kunt and Huizinga (1999), Athanasoglou et al. (2008), Hakimi and Zaghdoudi (2017), Hamdi and Hakimi (2019).

For the effect of macroeconomic variables, results show that the growth rate of GDP is positively and significantly correlated with the dependent variable for the three models. An increase of $5 \%$ in the GDP 
increases the net interest margin by $10.4 \%$ for model (1), $8.9 \%$ for model (2) and $9 \%$ for model (3). In the period of growth, it results an increase in the ability of borrowers to pay their loans that reduces nonperforming and improves bank performance. Furthermore, stable macroeconomic conditions motivate and stimulate investment when banks can grant more good loans. The good quality of these loans increases the interest income and bank performance. These findings are in line with the works of Calza et al. (2003) and Athanasoglou et al. (2008).

Findings indicate that bank performance is more sensitive to the inflation rates. We found that the net interest margin is negatively and significantly correlated with inflation. An increase of $1 \%$ in the inflation rate decrease bank performance by more than $40 \%$ for the three models. High inflation can distort bank financing decisions. Also, with high level of inflation, it results an increase of the interest income that increases NPLs and decreases bank performance. These results corroborate the work of Ben Naceur and Goaid (2008), Hakimi and Zaghdoudi (2017).

\section{Conclusion and Policy Recommendations}

The aim of this paper was to explore the dynamic interaction between operational risk, credit risk, liquidity risks and the Tunisian bank performance. To this end, we use bank level data related to ten (10) banks and macroeconomic variables over the period 2000-2017. Since the number of years $(\mathrm{N})$ is greater than the number of banks (i), we apply for the static panel data instead of dynamic panel data.

The empirical strategy followed in this paper is based on three steps. In the first step, we test separately the impact of operational risk proxied by the capital charges within the Basic Indicator Approach, loans activity (credit risk) and liquidity risk on bank performance. Empirical results of the model (1) indicate that an increase in capital charge necessary to hedge operational risk significantly increases the level of bank performance. The second step consists to test the impact of the interaction between operational risk and credit risk on the Tunisian bank performance. Empirical findings of the model (2) show that the interaction between operational risk and loans activity exerts a positive and significant effect on the level of bank performance measured by the net interest margin. In the third step, we tested the impact of the interaction between operational risk and liquidity risk on the Tunisian bank performance. Results show no significant effect of the interaction between operational and liquidity risk.

Findings also indicate that liquidity risk was found to be negatively and significantly correlated with the net interest margin for the model (1) and model (2). Furthermore, we found that loans activity as proxy for credit risk increases significantly the level of performance for the model (1) and model (3). For the Tunisian context, Banks are considered as loans based activity. Hence, any increase in the loans granted with sufficient guarantees significantly improves the performance of the Tunisian banks.

With regard to the effect of macroeconomic condition, bank performance benefits from an improvement of the level of growth while it is very sensitive to any changes in the inflation rate. In this study, bank size and capital are found to be without any significant effect on the bank performance.

These results could bring some important policy recommendations to policymakers toward a better hedge of bank risks precisely the operational risk. Since capital charge increases bank performance, Tunisian banks should increase the necessary capital that is able to hedge and manage this risk. Also, Tunisian banks are recommended to more strengthen their loans activity since it improves their performance, but they should grant more importance to the level of guarantees. Policymakers should take several economic and financial reforms in order to stabilize the macroeconomic context precisely the inflation rate that negatively affects the level of bank performance.

\section{End Notes}

1. For more details on the statistics of annual evolution of net interest margin and capital charge, see appendix

2. For more details on the statistics of the evolution of NIM and operational risk, see appendix 3. 
3. For more details on the names and ownership structure of the 10 Tunisian banks, see appendix 1.

4. For more details, see the section 3, the overview of the Tunisian banking system.

5. $K B I A=\left[\sum\left(\left.G\right|_{1 \ldots \ldots . . .} \times \alpha\right)\right] / n$, where $K B I A=$ capital charge under the Basic Indicator Approach; GI = annual gross income, $n=$ number of the previous three years for which gross income is positive; $\alpha=15 \%$, as determined by the Basel Committee, connecting between the requisite level of capital and Indicator $G$.

\section{References}

Al-Tamimi, H., Minaoui, H., \& Elkelish, W. W. (2016). Financial risk and Islamic bank's performance in the gulf cooperation council. The International Journal of Business and Finance Research, 9(5), 103-112.

Arif, A., \& Nauman Anees, A. (2012). Liquidity risk and performance of banking system. Journal of Financial Regulation and Compliance, 20, 182-195.

Athanasoglou, P., Brissimis, S., \& Delis, M. (2008). Bank-specific, industry-specific and macroeconomic determinants of bank profitability. Journal of International Financial Markets. Institutions and Money, 18(2), 121-136.

Bikker, J. A., \& Hu, H. (2002). Cyclical patterns in profits, provisioning and lending of banks and procyclicality of the new Basel capital requirements. BNL Quarterly Review, 221, 143-175.

Bourke, P. (1989). Concentration and other determinants of bank profitability in Europe, North America and Australia. Journal of Banking and Finance, 13, 65-79.

Calza, A., Gartner, C., \& Sousa, J. (2003). Modelling the demand for loans to the private sector in the euro area. Applied Economics, 35, 107-117.

Gadzo, S. G., Kportorgbi, H. K., \& Gatsi, J. G. (2019). Credit risk and operational risk on financial performance of universal banks in Ghana: A partial least squared structural equation model (PLS SEM) approach. Cogent Economics \& Finance, 7(1), 1-16.

Hakimi, A., \& Zaghdoudi, K. (2017). Liquidity risk and bank performance: An Empirical test for Tunisian banks. Business and Economic Research, 7(1), 46-57

Hamdi, H., \& Hakimi, A. (2019). Does liquidity matter on bank profitability? Evidence from a nonlinear framework for a large sample. Business and Economics Research Journal, 10(1), 13-26.

Kargi, H.S. (2011). Credit risk and the performance of Nigerian banks. AhmaduBello University, Zaria.

Kasman, A. (2010). Consolidation and commercial bank net interest margins: Evidence from the old and new European Union members and candidate countries. Economic Modeling, 27, 648-655.

Kithinji, A. M. (2010). Credit risk management and profitability of commercial banks in Kenya. University of Nairobi, School of Business, Nairobi.

Micco, A., Panizza, U., \& Yanez, M. (2007). Bank ownership and performance. Does politics matter? Journal of Banking and Finance, 31(1), 219-241.

Molyneux, P., \& Thornton, J. (1992). Determinants of European bank profitability: A Note. Journal of Banking and Finance, 16(6), 1173-1178.

Muriithi, J. G., \& Waweru, K. M. (2017). Operational risk, bank size and the financial performance of commercial banks in Kenya. Journal of Finance \& Banking Studies, 6(3), 39-50.

Olalere, O., Islam, M. A., \& Sallha, Y. W. (2018). An investigation into operational risk in commercial banks: Empirical evidence from Nigeria. International Journal of Accounting, Finance and Business, 3(12), 49-62.

Pasiouras, F., \& Kosmidou, K. (2007). Factors influencing the profitability of domestic and foreign commercial banks in the European Union. Research in International Business and Finance, 21(2), 222-237.

Schwaiger, M.S., \& Liebig, D. (2008). Determinants of bank interest margins in Central and Eastern Europe. Financial Stability Report, 14, 68-87

Staikouras, C., \& Wood, G. (2004). The determinants of European bank profitability. International Business and Economics Research Journal, 3(6), 57-68.

Stiroh, K. J., \& Rumble, A. (2006). The dark side of diversification: the case of U.S. financial holding companies. Journal of Banking and Finance, 30(8), 2131-2161. 


\section{Appendix}

Appendix 1. Names and Ownership Structure of the 10 Tunisian Banks

\begin{tabular}{|l|l|l|l|}
\hline & Abbreviations & Full Name & Public or Private \\
\hline 1 & AB & Amen Bank & Private \\
2 & ATB & Arab Tunisian Bank & Private \\
3 & ATTIJARI & Attijari Bank & private \\
4 & BIAT & International Arab Tunisian Bank & private \\
5 & BH & Housing Bank & public \\
6 & BNA & National Agricultural Bank & Public \\
7 & BT & Tunisian Bank & Private \\
8 & STB & Tunisian Company of Banks & Public \\
9 & UBCI & Union Banks of Trade and Industry & Private \\
10 & UIB & International Union of Banks & Private \\
\hline
\end{tabular}

Source: Tunisian Central Bank and Tunisian Association of Banks and Financial Establishments

Appendix 2. Average Annual Evolution of Net Interest Margin and Capital Charge (2000-2017)

\begin{tabular}{lccccccccc}
\hline Years & $\mathbf{2 0 0 0}$ & $\mathbf{2 0 0 1}$ & $\mathbf{2 0 0 2}$ & $\mathbf{2 0 0 3}$ & $\mathbf{2 0 0 4}$ & $\mathbf{2 0 0 5}$ & $\mathbf{2 0 0 6}$ & $\mathbf{2 0 0 7}$ & $\mathbf{2 0 0 8}$ \\
\hline $\begin{array}{l}\text { NIM in \% } \\
\begin{array}{l}\text { Capital charges } \\
\text { in MD }\end{array}\end{array}$ & 4.00 & 3.93 & 3.79 & 3.54 & 3.32 & 2.24 & 2.22 & 2.63 & 2.30 \\
\hline Years & $\mathbf{2 0 0 9}$ & $\mathbf{2 0 1 0}$ & $\mathbf{2 0 1 1}$ & $\mathbf{2 0 1 2}$ & $\mathbf{2 0 1 3}$ & $\mathbf{2 0 1 4}$ & $\mathbf{2 0 1 5}$ & $\mathbf{2 0 1 6}$ & $\mathbf{2 0 1 7}$ \\
\hline NIM in \% & 1.71 & 2.40 & 2.27 & 2.35 & 1.64 & 2.52 & 2.27 & 2.14 & 2.10 \\
$\begin{array}{l}\text { Capital charges } \\
\text { in MD }\end{array}$ & 7705.29 & 8508.12 & 9092.95 & 9853.27 & 10731.44 & 11823.56 & 12914.31 & 14039.26 & 15903.27 \\
\hline
\end{tabular}

Source: Authors calculation from the annual report of banks

Appendix 3. Average Evolution of Net Interest Margin and Capital Charge per Banks

\begin{tabular}{lcc}
\hline Banks & Capital charges in MD & Net Interest Margin in \% \\
\hline BNA & 11065 & 2.660 \\
STB & 10746 & 1.987 \\
BH & 9055 & 2.668 \\
BIAT & 14962 & 3.188 \\
UIB & 7483 & 2.995 \\
ATTIJARI & 8102 & 2.503 \\
BT & 7316 & 3.471 \\
UBCI & 5665 & 2.447 \\
AB & 7653 & 2.699 \\
ATB & 6394 & 1.689 \\
\hline
\end{tabular}

Source: Authors calculation from the annual report of banks 